or known from any other plant source. As well as in belladonna leaves, arginase has been found in the roots, in scions grafted on tomato stocks, in Datura stramonium and other solanaceous plants.

There are thus solid grounds for presuming that the nitrogen of the tropane alkaloids is derived from the $\delta$-amino group provided by the arginineornithine group of amino-acids, and that the $\alpha$-amino nitrogen of the other acids and the ring nitrogen of proline are not utilizable in the synthesis.

${ }^{1}$ Oxford Medicinal Plants Scheme, Annual Reports 1941-2-3-4-5.<smiles>C1C2CC1C2</smiles>

\section{THE NEW BODLEIAN LIBRARY AT OXFORD}

\section{By Dì' A. S. RUSSELL}

N Octoperr. 24 the King, in presence of the $\cup$ Queen, Ior Halifax, Chancellor of the University of Qxford, Sir Giles Gilbert Scott, architect of the builqing and a distinguished Oxford gathering, opedad the bow Library which has been erected at the corner of Broad Street and the Parks Road. The cost has been about $£ 660,000$, much of which was generously given to the University by the Rockefeller Trustees. Work on the building started in December 1936, and in the summer of 1937 the foundationstone was laid by Queen Mary. The building was finished in 1940, and, but for the War, would have been formally opened in June of that year.

The New Library, as it is to be called, is a square stone block with frontages $41 \mathrm{ft}$. in height surrounding a central mass which rises $78 \mathrm{ft}$. above the street-level. The main problem for the architect and his helpers was how to get accommodation for five million books on a small site near the old Bodleian Library in the heart of the University area, where buildings of many periods are all low. Twelve years ago the University rejected the suggestion that the new building should stand by itself outside of the busy area. In consequence, a plan like that of the Cambridge Library, with book-stacks naturally lighted around open courts, and with a high central tower, was not feasible. The plan adopted was something like that of the new Library of Columbia University" or of the annexe to the Library of Congress at Washington. In the centre is the main book-stack, starting many feet below ground-level and rising only to a height of $78 \mathrm{ft}$. It has eleven decks, each a little more than $7 \mathrm{ft}$. in height, of which three are below the ground and extend under the whole site. Six of the eight decks above the ground are entirely surrounded by the three floors of the outer range of rooms, and consequently, like the basement, are dependent on electric power for their lighting and ventilation. The topmost two decks of the stack rise above the rest of the building and so can be naturally lighted. The decks are fitted throughout with ranges of steel stack interrupted by gangways and having passages of about $2 \mathrm{ft} .6 \mathrm{in}$. wide between each range. There are many lifts and internal staircases to allow of communication between the decks. Throughout the stack there is plenum and extract ventilation, and the whole building is heated by water coming from a thermal storage plant in the basement.

Surrounding this great stack are the outer rooms, the frontages of which rise in three stories only. As room for many library needs are already adequately met in Bodley's Library, the Radcliffe Reading Room, the Radeliffe Science Library and the departmental University libraries elsewhere, the New

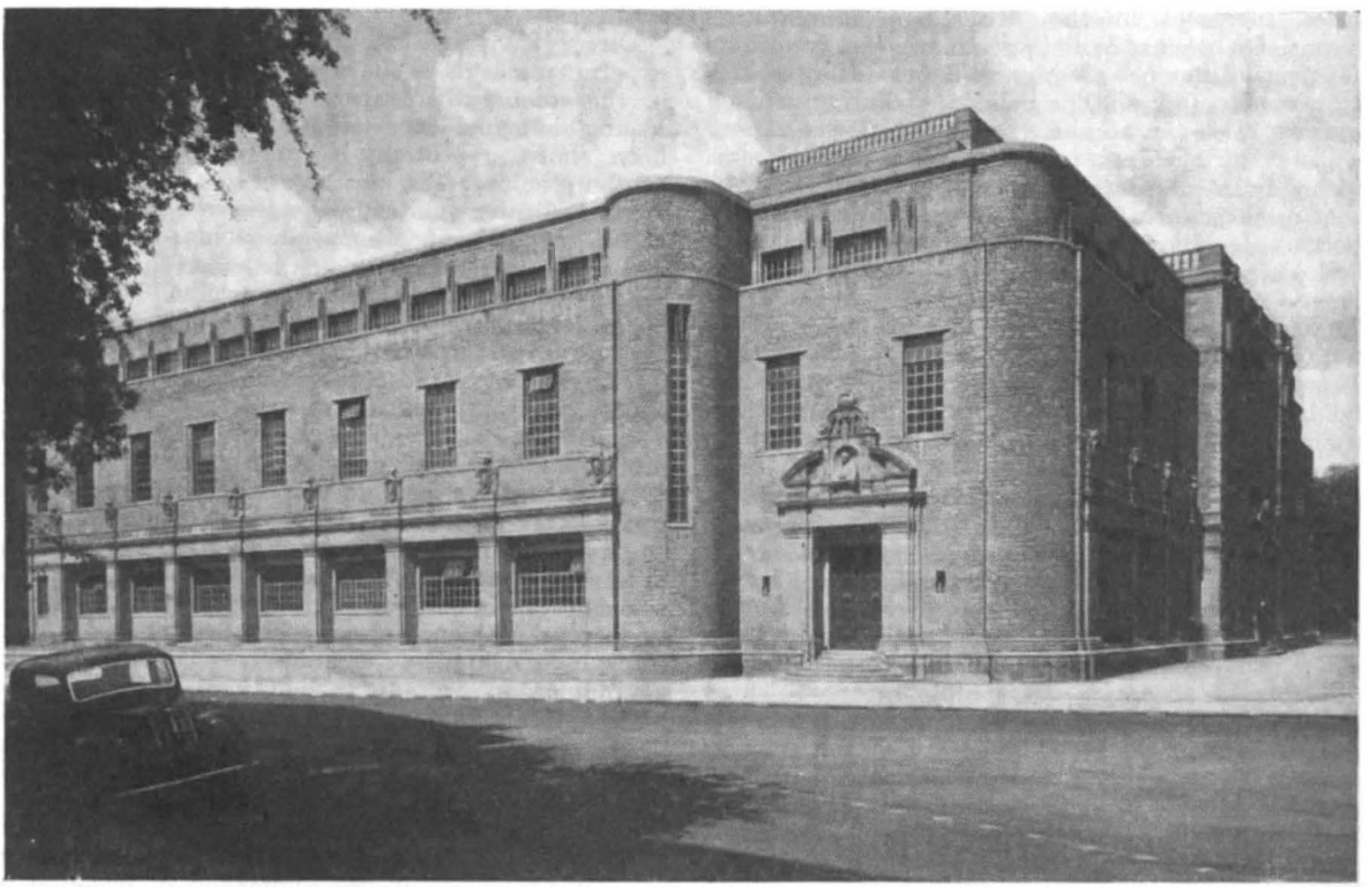


Library rooms will be used mainly for special purposes. There are rooms for photography and for the reading of microfilms. There are a map room, a catalogue room, a bindery, a reading room able to accommodate eighty readers, and many rooms for research workers. The New Library, although its main purpose is to house millions of books, will help towards making them more accessible, especially for senior members of the University and those engaged in co-operative research.

Oxford differs from Cambridge in that books from its University library may not be taken out of it. Access to the stack, which will be granted to all serious readers wishing to have it, is thus of importance. A good deal of attention, also, has been paid to getting books from the stack quickly to readers in various parts of the old Library. A tunnel under the intervening street connects the basements of the old and the new Library, and a mechanical conveyor is at work there. This enables books to be taken to and fro from all floors on both buildings. A book starting from the stack, for example, descends to the basement, goes through the tunnel under the street and ascends to the old Library, where it is automatically discharged at the correct floor-level. There are ingenious devices so that messages can be sent quickly almost anywhere in the area, and the systems of ventilation and of air-conditioning ensure that the central heating will not damage, even over periods of years, the books that are housed there.

There can be no expansion on this site. It is not anticipated, however, that the new building will be full for another two hundred years at the present rate of intake of books. It is interesting to note how books can accumulate. In 1822, Bodley's Library had a modest total of 160,000 volumes. In 1888 this had risen to 440,000 , and in 1915 to $1,000,000$. Every year this growth--benign or otherwise as it may be viewed-has increasingly overflowed into neighbouring buildings and basements, and produced the attendant inconveniences of lack of access and delay. It has had one good effect. It has compelled the central library to be less hostile to the setting up of departmental libraries with open shelves. At one time the Radcliffe Science Library in the area of the Laboratories, with its open shelves, had to buy books, copies of which Bodley's Library received gratis and hid inaccessibly away. Since 1927, however, the science books in the old Library go straight to the Radcliffe Science Library, where the conditions for access are unsurpassed. Despite the setting up of such departmental libraries on various sites, the space available for books in the main Library would have completely vanished by 1940 .

Not everybody likes the outside of the Library. It fits in with its neighbours moderately only, but its solid unpretentiousness grows on one with time. Dignified efficiency and an almost complete absence of ornament or architectural effects are what impress the visitor most in the interior. It is 'utility'. raised almost to the point of genius. It is a civilized place for working in. It is the antithesis of some parts of the old Library, the characteristic of which was a funereal gloom, where no candle, lamp or even electric light was allowed for risk of fire. Sir Thomas Bodley, it is not generally known, was a lover and collector, in his day, of scientific instruments, and his ghost may well view the magnificent addition to the Library which he founded, where applied science has been summoned to bring books and readers comfortably together, not with consternation but with delight.

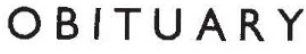

\author{
Dr. Charles S. Myers, C.B.E., F.R.S.
}

WHEN the complet hot of the last forty years of development of $/$ xperimental and applied psy. chology in Brifowors written, it will become clear that an enormgus dmount of this development was due directly to the enthusiasm, foresight, scientific know. ledgefand organising skill of Dr. C. S. Myers. For same time there was no certainty that psychology would claim him for life. Literature, music, philos. ophy, archæology all attracted and held him, as well as natural science. It was, however, as a student of natural science that he gained an exhibition at Gonville and Caius College in 1891, and later a scholarship. He had a distinguished student career at Cam. bridge, where his interests turned chiefly in the direction of biological studies, and from physiology and anatomy he went on, through the influence of Rivers and Haddon, to oxperimental psychology and anthropology.

Myers left Cambridge in 1895 and decided to take a medical qualification, looking forward, however, not to medical practice but to a life of research. As it turned out, he was offered, and accepted, a place in Haddon's expedition to the Torres Straits, and this was a crucial decision. He joined Rivers in an experimental study of the special senses and reactiontimes of the natives of that area, and himself carried out his pioneer research into some of the characteristics of primitive music. Henceforward, psychology became the chief concern of his working life.

Back again in Cambridge in 1902, Myers began to assist Rivers in the teaching of experimental psychology in three rooms of a dilapidated building which were vacated by the pathologists. Students increased in number, and within a year psychology moved to a cottage which belonged to the University Press. Myers was still, justifiably, dissatisfied. He was working part of his time as professor of psychology at King's College, London, part of his time at Cambridge, and was engaged upon his famous "Text Book of Experimental Psychology". It was a busy life, but Myers still found time to agitate, organise, plan ceaselessly and in the face of frequent disappointments, for an adequate base in Cambridge for the subject that was nearest to his heart. In 1911, two years after he had given up his work in London, the first real steps were taken, and in 1912 the Cambridge Laboratory of Experimental Psychology, provided to an extent that few people ever fully realized by the splendid gifts of himself and his friends, became a permanent memorial to his energy and drive.

Before the new Laboratory could get into full swing, the First World War broke out. Myers surmounted all the difficulties that were put in his way and went overseas. He became eventually consultant psychologist to the British Armies in France. Here his very great organising and administrative skill for the first time got something like an adequate scope, though it was not until the Second World War that the work he then did came to full flower. More and more now his intarests were turning to applied fields. He wanted to go on using psychology in the interests of medicine, industry, education and the Fighting Services. He was restless and even unhappy in academic life. In 1922 he severed his official connexion with Cambridge, and became the 